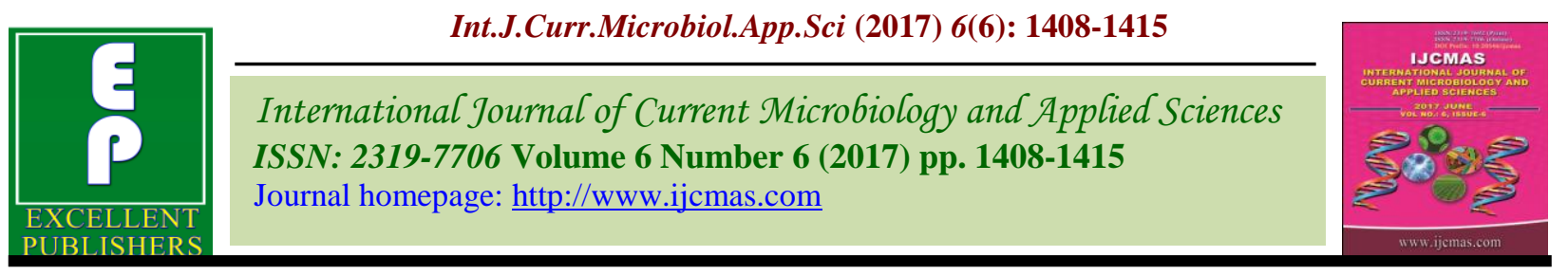

Review Article

https://doi.org/10.20546/ijcmas.2017.606.165

\title{
The Multipurpose Utilization of Coconut By-Products in Agriculture: Prospects and Concerns
}

\author{
Shiva Kumar Udayana ${ }^{1 *}$, Anandkumar Naorem² and Naorem Arunkumar Singh ${ }^{1}$ \\ ${ }^{1}$ Department of Agricultural Chemistry and Soil Science, Bidhan Chandra Krishi \\ Viswavidyalaya Mohanpur, Nadia, West Bengal-741252, India \\ ${ }^{2}$ KVK (ICAR), West Garo Hills, Tura, Sangsanggiri, Meghalaya-794005, India \\ *Corresponding author
}

Keywords

Coconut,

Coco peat, Coir pith, Hydroponics, Soil amendment.

Article Info

Accepted:

19 May 2017

Available Online:

10 June 2017

\section{A B S T R A C T}

The by-products obtained from the coconut industry goes out as waste and pollute the environment, if not properly managed. In order to convert these by-products such as coir pith and coco peat into a natural organic resource, it is processed and utilized as an economical input in agriculture as well as in horticulture. Processed coir pith is used as an excellent soil amendment because of its favourable physical properties in maintaining soil health. In addition to this, it finds its importance as medium for rooting for plants, hardening of air layers, storage of scions and horticultural produce. With its special characteristics of maintain high water holding capacity, it is gaining its interests in rain fed agriculture. Use of these by-products as mulch, remediation product, disease suppression, hydroponics etc. adds to its quality. Bringing out the several applications of coir pith/ coco peat, it deserves to gain the attention of the researchers to stud on its usefulness and its potential in food production.

\section{Introduction}

In India, according to Coconut Development Board, India, 1975, 81 thousand hectares of land is under coconut cultivation according to a data provided by Coconut Development Board, India in the year 2014-2015. The productivity of coconut cultivation is 10345 nuts/ha in the year 2014-2015 with south Indian states especially Kerala, Karnataka and Tamil Nadu (Mathew, 2004) occupying the largest area of coconut production. The endosperm of the coconut is utilized for human consumption whereas the by-products serve as raw materials for manufacturing several other value added products. These byproducts are now studied for use in agriculture in a view to supplement or replace the inorganic fertilizers or other costly inputs used in cultivation by processing the byproducts into more productive form (Prabhuand Thomas, 2002). The present paper will focus on by-products of coconut and their utilization in agriculture. Coconut (Cocusnucifera L.) pith or coir (botanically mesocarp of the fruit), is a by-product product 
in coconut production and it has been studied in different areas of research because of its physical and chemical properties favourable for many purposes (Prabhu and Thomas, 2002).Coir pith is defined as an agro-waste produced during coir fibre extraction, constituting about $70 \%$ of coconut husk (Pazhanivel et al., 2011).

\section{Why coir pith or cocopeat?}

Among various by-products, interest is developed on coir pith due to several reasons one of which is the limitation in the availability and accessibility of other organic manures such as compost, FYM, green manure etc. Coir pith are conventionally used in land fillings and manuring purposes. However, the quantity of waste produced per year seems to be a difficult cause and a problem in polluting aquatic as well as terrestrial environment.

In addition to this, due to inappropriate disposal, during rainy season, chemicals found in coir pith such as polyphenols and organic matter may leach out leading to hiking of BOD and COD in aquatic environment (Pazhanivel et al., 2011). The dumping of the coir pith itself in water bodies may increase the concentration of hydrogen sulphide, methane and carbon dioxide that are toxic gases (Paramanandhamand Ross, 2015). Therefore, it calls the attention of all workers and researchers to investigate and assess more information on sustainable utilization of this agro waste into productive manner.

But, with proper management and storage, coir pith can be an excellent agricultural input. Coco peat has high moisture retaining capacity, high total pore spaces, low bulk density and slow biodegradation (Awang et al., 2009; Treder and Nowak, 2002; De Kreij and Leeuven, 2001). Another reason is the non-renewable capacity of peat and legal restriction in using peat in some regions.
Therefore, coco peat is being tested as a supplement or substitution to peat as it is renewable and has peat-like properties. Coco peat has favourable $\mathrm{pH}$ which is found to be optimum for many plants whereas peat is highly acidic. So, it reduces the cost of cultivation by reducing the cost of liming (Cresswell, 2011).

\section{Utilization of coconut by-products in agriculture}

\section{Soil amendment}

Soil amendments are those materials when added to soil, it must modify the soil properties in a positive way so as to make the soil healthy. Coir pith is especially of high demand in dry areas due to its high moisture retaining capacity around 40\% (Paramanandham et al., 2014). Paramanandham and Ross (2015) and Pavithran (1993) studied the microstructure of coir pith compounds and observed the presence of numerous open cells forming large empty cavities, forming as capillaries for water and nutrient adsorption. When coir pith was added to clayey soil, it modifies the stickiness of the clay soil and enhances the drainage properties of the soil (Mayalagu, 1983).

Application of coir pith as soil amendment in long term basis could reduce the bulk density, increase the water holding capacity and improve the organic carbon content of soil (Muthurayar and Dhanarajan, 2013). The low particle density of coir pith itself is due to its high specific surface that results in high cation exchange capacity of around 38.9-60 $\mathrm{meq} / 100 \mathrm{~g}$, which is favourable for adsorption of sufficient amount of nutrients for the plants (Jeyaseeli and Raj, 2010). Moreover, according to Kadalli et al., 2001a, decomposition of coir pith produced humic compounds from the lignin compounds and it improves nutrient adsorptive capacity. 


\section{Horticulture purposes}

Coco peat finds its proper applicability in the cultivation of horticultural crops as shown in table 1. Additionally, the humic substances in coco peat play important role in making it suitable for use in plant propagation and culture of plants, as humic substances are known to have hormone-like activity and can stimulate root and plant growth (Prabha et al., 2013).

\section{Planting/potting medium}

A good pot culture medium must be a good source of nutrients and water besides providing support to the growing plants. Coco peat possesses these properties in addition to its low weight (Prasad and Roeber, 1997).

Singh, 1998 investigated the utilization of coco peat as rooting medium and found that it was a better substitute to commercial peat. Coco peat is also an excellent pot culture medium, if washed repeatedly with deionized water to leach out chloride and sodium (Jeyaseeli and Raj, 2010).

\section{Reclaimation and remediation of soils}

Many organic sources are tested for their efficiency in reclaiming degraded soils in a sustainable way. In certain problem soils, coir pith has been studied for its potential in remediation of polluted affected soils. Jayakumar et al., (1997) and Singarum (1994) reported that crops grown in coir pith amended soil (polluted with tannery effluents) showed an increase in yield as compared to the soil without coir pith.

Santiago and Santhamani (2010) reported the use of coir pith in remediation process of a chromium contaminated soil. It was found to be important in reclaiming salt affected soils (Marimuthu and Nagarajan, 1993; Clarson,
1986) by decreasing the salt crust formation and helping in cation exchange process to reduce exchangeable sodium percentage (ESP).

\section{Soil less culture medium}

Soilless media are commercialized among the consumers because of its good consistency, proper aeration, and low bulk density with fewer risks in shipping and transportation costs (Nazari et al., 2011).

Joseph and Muthuchamy (2014) reported the importance of coir pith enhanced with nutrients in a soil less medium. Soilless culture medium is effective in enhancing water use efficiency and improves the nutrient management in cultivation of the crops.

Coco peat is found to be one of the best ingredients in soilless culture medium, replacing sphagnum peat as reported by Hussain et al., (2014) and Pill and Ridely (1998).

\section{Integrated nutrient management}

Coir pith compost is a good source of nutrients and performs better when enriched or blended with nutrients (Thomas et al., 2013; Kumar and Ganesh, 2012; Ghosh et al., 2007). Uthiah et al., (1993) reported that application of coir pith around the coconut tree at radius of 1 metre and a thickness of 10 $\mathrm{cm}$ increased the yield by $25 \%$.

Blended coir pith enriched with calcium and magnesium nitrate at $7 \mathrm{~g} / \mathrm{l}$ performed equally with the media amended with neem cake and bone meal mixture (Ross, 2002). As coir pith is acidic, it also enhances the release of occluded and mineral potassium in soil, cutting down the demand and need of external potash fertilizers (Savithri and Hameed, 1994). 
Table.1 Applications of coir pith/ coco peat in horticulture

\begin{tabular}{|c|c|c|}
\hline Applications & Test crops & References \\
\hline \multirow[t]{4}{*}{ Rooting of plant cuttings } & Psidiumguajava & Sardoei, 2014 \\
\hline & Acalypha & Lokeshaet al., 1988 \\
\hline & Bougainvillea & Lokeshaet al., 1988 \\
\hline & Eucalyptus & Wattieret al., 1998 \\
\hline \multirow[t]{2}{*}{ Compost for orchids } & Lilies & Treder, 2008 \\
\hline & Dendrobium & Catibod, 2000 \\
\hline \multirow[t]{2}{*}{ Air layering } & Punicagranatum & Patel et al., 2012 \\
\hline & Psidiumguajava & Mauryaet al., 2012 \\
\hline \multirow[t]{2}{*}{ Hardening of air layers } & SinningiaspeciosaHierm & Kashyap and Dhiman, 2011 \\
\hline & Saintpauliaionantha & Kashyap and Dhiman, 2011 \\
\hline Storage of scion & Qutmeg & $\begin{array}{l}\text { Rema and Krishnamoorthy, } \\
1998\end{array}$ \\
\hline $\begin{array}{l}\text { Storage of horticultural } \\
\text { produce }\end{array}$ & Banana & Thompson et al., 1974 \\
\hline
\end{tabular}

Table.2 Table depicting the disease suppressing ability of coir pith

\begin{tabular}{|c|c|c|c|}
\hline Forms of coir pith & $\begin{array}{l}\text { Pathogens/ disease } \\
\text { suppressed }\end{array}$ & Remarks & References \\
\hline \multirow[t]{2}{*}{ Processed coir pith } & Phytophthora capsici & Suppressed & $\begin{array}{l}\text { Hyder et al., } \\
2009\end{array}$ \\
\hline & Fusarium solani & Suppressed & $\begin{array}{l}\text { Hyder et al., } \\
2009\end{array}$ \\
\hline $\begin{array}{l}\text { Coir pith composted } \\
\text { using Pleurotus } \\
\text { djamor at the rate of } \\
10 \text { tha }^{-1}\end{array}$ & $\begin{array}{l}\text { Dry rot disease of black } \\
\text { gram caused by } \\
\text { Macrophomina } \\
\text { phaseolina }\end{array}$ & $\begin{array}{l}\text { Comparable to the } \\
\text { application of } 0.1 \% \\
\text { carbendazim }\end{array}$ & $\begin{array}{l}\text { Ramamoorthy et } \\
\text { al., 1999b }\end{array}$ \\
\hline Decomposed coir pith & $\begin{array}{l}\text { Root diseases } \begin{array}{r}\text { of } \\
\text { capsicum and black } \\
\text { gram }\end{array} \\
\end{array}$ & Effective & $\begin{array}{l}\text { Theradimani and } \\
\text { Marimuthu, } \\
\text { 1993b }\end{array}$ \\
\hline Processed coir pith & $\begin{array}{l}\text { Damping off caused by } \\
\text { Rhizoctonia solani and } \\
\text { Fusarium equiseti }\end{array}$ & Effective & $\begin{array}{l}\text { Marimuthu and } \\
\text { Nagarajan, } 1993\end{array}$ \\
\hline
\end{tabular}

In rainfed agriculture, use of coir pith is found to be extensive as it regulates the moisture level in soil thereby conserving more water. Moreover, coir pith is rich in potassium $(0.8 \%)$ and therefore, plays a crucial role in osmoregulation of the crops (Savithri and Hameed, 1994). The nutrient use efficiency of nitrogeneous fertilizers is often low owing to its various ways of losses. Nitrification inhibitors are used in this case to increase the nutrient use efficiency by regulating the rate of nitrification (Prasad et al., 1971). Chemicals present in coir pith such as polyphenols and tannins of plant origin are effective in retarding the nitrification process (Baldwin et al., 1983; Sivapalan and Fernando, 1983; Basarba, 1964). 


\section{Suppressing pathogens}

In addition to the favourable physical characteristics of coco peat, it has also inherent properties to plant disease suppressing capacity. Coco peat can suppress many fungal diseases (Hyder et al., 2009; Ramamoorthy et al., 1999b) and because of this additional benefit, it is likely that it will become a part of integrated disease management systems for horticultural crops as shown in table 2 .

\section{Horizontal mulch}

Coir pith has high $\mathrm{C}$ : $\mathrm{N}$ ratio, slow decomposition rate and high moisture retaining capacity, which makes it suitable for good mulch (Solaimalai et al., 2001).

\section{Limitations}

The residence time of coir pith in environment is long enough to cause pollution, if it is not managed properly. The amount of waste generated from the coconut industry is large and creates the disposal problem due to its high lignocellulosic material which is decomposed in a slower rate. Therefore, for the lignins to be decomposed, specific micro-organisms are needed for its degradation. Coir pith must be processed to be use in different agricultural purposes; otherwise, the raw, natural form is not conducive for growth of crops as it has high C: N ratio (Wang et al., 1967). Although coir pith is rich in potassium, it is comparatively deficient in nitrogen and phosphorus (Abad et al., 2002). In addition to it, the presence of chemical compounds such as soluble tannin related phenolics compounds do not favour the growth and development of plants (Thampan, 2000). In few times, coco peat causes negative impact on air-water relation through high water level, thus creating poor aeration and influencing oxygen diffusion rate to roots of the plants. Yau and Murphy (1998) reported the inhibition of root growth in Lepidium sativum by application of raw coir pith extracts. They also reported that farmers who used raw coir pith complained that crops developed chlorosis symptoms.

Despite of few limitations, agro-waste products of coconut industry can be utilized as important inputs in agriculture and horticulture with proper processing methods and management. These by-products might efficiently supplement the integrated nutrient management and could be one of the economical inputs in maintaining soil heath. With all these information, it can be concluded that further research on these byproducts might bring out more usefulness of these waste and aids in successful sustainable agriculture.

\section{References}

Abad, M., Noguera, P., Puchades, R., Maquieira, A. and Noguera, V. 2002. Physico-chemical and chemical properties of some coconut coir dust for use as a peat substitute for containerized ornamental plants. Biores. Technol., 82: 241-245.

Ali, S.S. 2014 Effect of different media of cuttings on rooting of guava (Psidium guajava L.). Eur. J. Exp. Biol., 4(2): 8892.

Baldwin, L.T., Olson, R.K. and Reiners, W.A. 1983. Protein binding phenolics and the inhibition of nitrification in subalpine balsam fir soils. Soil Biol. Biochem., 15: $419-423$.

Basmba, J. 1964. Influence of vegetable tannins on nitrification in soil. Plant Soil, 21: 8-16.

Bharati, K. and Dhiman, S.R. 2011. Effect of media on hardening of in vitro multiplied plantlets of gloxinia and 
saintpaulia under low cost polytunnels. Int. J. Farm Sci., 1(2): 63-67.

Catibod, N.A. 2000. Compost from coco coir dust. PCARRD Moniot., 28(1): 6 .

Clarson, D. 1986. Coir dust for economic reclamation of saline-alkali soils and for better profit. Indian Coconut J., 14(9): 6-9.

Cresswell, G. 2011. Coir Dust A Proven Alternative to Peat, Cresswell Horticulrutal Services, pp. 1-13. (Report).

De Kreij, C. and Leeuven, G.J.L. 2001. Growth of pot plants in treated coir dust as compared to peat. Commun. Soil Sci. Plant Analysis, 32: 2255-2265.

Ghosh, P.K., Sarma, U.S., Ravindranath, A.D., Radhakrishnan, S. and Ghosh, P. 2007. A novel method for accelerated composting of coir pith. Energy Fuels, 21: 822-827.

Hussain, A., Iqbal, K., Aziem, S., Mahato, P. and Negi, A.K. 2014. A review on the science of growing crops without soil (soilless culture) - A novel alternative for growing crops. Int. J. Agri. Crop Sci., 7(11): 833-842.

Hyder, N., Sims, J.J. and Wegulo, S.N. 2009. In Vitro Suppression of Soilborne Plant Pathogens by Coir. Hort. Technol., 19(1): 96-100.

Jayakumar, M., Eyini, M. and Velmurugan, R. 1997. Effect of seed Rhizobium pelleting treatment and addition of coirpith compost to soil on growth and nodulation of fluoride water irrigated blackgram (Phaseolus mungo). Indian J. Agri. Sci., 67: 610-603.

Jeyaseeli, D.M. and Raj, S.P. 2010. Chemical characteristics of coir pith as a function of its particle size to be used as soilless medium. Ecoscan, 4(2\&3): 163-169.

Joseph, A. and Muthuchamy, I. 2014. Productivity, Quality and Economics of Tomato (Lycopersicon esculentum Mill.) Cultivation in Aggregate
Hydroponics - A Case Study from Coimbatore Region of Tamil Nadu. Indian J. Sci. Technol., 7(8): 10781086.

Kadalli, G.G., Suseela Devi, L., Siddaramappa, R. and John, E. 2001a. Characterization of humic fractions extracted from coirdust- based composts. J. Indian Soc. Soil Sci., 48: 51-55.

Lakshmi Prabha, M., Shanmugapriya, M. and Soniya, D. 2013.Composting of coir pith using biopond effluent from effluent treatment plant of petrochemical division. Int. J. $A d v$. Pharmacy, Biol. Chem., 2(1): 173-178.

Lokesha, R., Mahishi, D.M. and Shivashankar, G. 1988. Studies on use of coconut coir dust as a rooting media. Curr. Res., 17: 157-158.

Marimuthu, T. and Nagarajau, R. 1993. Coir pith: A useful crop residue. Biol. Edu., 161-164.

Mathew, M.T. 2004. Coconut industry in India: An overview. Indian Coconut J., 35(7): 3-17.

Maurya, R.K., Ray, N.R., Chavda, J.C., Chauhan, V.B. and Patil, A.K. 2012. Evaluation of different organic media and water holding materials with IBA on rooting and survival of air layering in guava (Psidium guajava L.) cv. Allahabad Safeda, Asian J. Horticult., 7(1): 44-47.

Mayalagu, K., et al. 1983. In: Proc. National Seminar on Utilization of Organic Wastes, AC \& RI. Madurai, Tamil Nadu, pp. 116-118.

Muthurayar, T. and Dhanarajan, M.S. 2013. Biochemical changes during composting of coir pith waste as influenced by different agro industrial wastes. Agri. Sci., 4(5B): 28-30.

Nazari, F., Farahmand, H., Khui, M.K. and Salehi, H. 2011. Effects of coir as a component of potting media on growth, 
flowering and physiological characteristics of hyacinth (Hyacinthus orientalis L. cv. Sonbol-e-Irani). Int. J. Agri. Food Sci., 1(2): 34-38.

Paramanandham, J. and Ronald Ross, P. 2015. Scanning electron microscopic analysis of coir pith after subjected to different treatments. Recent Trends in Physical Chem.: An Int. J., 2(1): 1-3.

Paramanandham, J., Ronald Ross, P., Abbiramy, K.S. and Muthulingam, M. 2014. Studies on the moisture retention capacity of coir pith, as a function of time. Int. J. Chem. Tech. Res., 6(12): 5049-5052.

Patel, D.M., Nehete, D.S., Jadav, R.G. and Satodiya, B.N. 2012. Effect of PGR's and rooting media on air layering of different pomegranate (Punica granatum L.) cultivars. The Asian $J$. Horticulture, 7(1): 89-93.

Pavithran, C. 1993. Possibility of using coconut pith as a matrix for controlled/slow release systems in agriculture. Paper presented at the workshop on utilization of coir pith, Pollachi on 13 feb.1993, Coir Board, Cochin.

Pazhanivel, G., Chandrasekaran, P., Prabha, D.S., Bhuvaneswari, B., Malliga, P. and Chellapandi, P. 2011. Effect of coir pith based cyanobacterial biofertilizer for improving fatty acid contents in Arachis hypogaea L. (Groundnut) oil seeds. $J$. Adv. Develop. Res., 2(1): 38-41.

Pill, W.G. and Ridely, K.T. 1998.Growth of tomato and coreopsis in response to coir dust in soilless media. Hort. Tech., 8: 401-406.

Prabhu, S.R. and George, V.T. 2002. Biological conversion of coir pith into a value-added organic resource and its application in Agri-Horticulture: Current status, prospects and perspective. J. Plant. Crops, 30(1): 117.
Prasad, M. and Roeber, R.U. 1997. Physical, chemical and biological properties of coir dust. Acta Horticulturae, 456: 2129.

Prasad, R., Rajale, G.B. and Lakhdive, B.A. 1971. Nitrification retarders and slow release nitrogen fertilizers. Adv. Agron., 23: 337-383.

Rema, J. and Krishnamoorthy, B. 1998. Effect of packing materials and storage of scions on graft success in nutmeg (Myristica fragrans). J. Spices and Aromatic Crops, 7: 147-148.

Roonamoorthy, M., Muthusamy, M., Meena, B., Sitharaman, K. and Alice, D. 1999b. Composting of coir pith using lignocellulolytic fungi for the management of root rot of black gram. Mushroom Res., 8: 13-17.

Santiago, M. and Santhamani, S. 2010. Remediation of chromium contaminated soils: Potential for phyto and bioremediation. 19th World Congress of Soil Science, Soil Solutions for a Changing World 1 - 6 August 2010, Brisbane, Australia.

Savithri, P. and Hameed, K.H. 1994. Characteristics of coconut coir peat and its utilization in agriculture. $J$. Plantation Crops, 22: 1-18.

Singarum, P. 1994. Effect of coir pith as an amendment for tannery polluted soils. Madras Agri. J., 81: 548-549.

Sivapalan, K. 1952. Humification of polyphenol-rich plant residues. Soil Biol. Biochem., 14: 309-310.

Solaimalai, A., Ramesh, P.T. and Ravisankar, N. 2001. Utilization of raw coir pith in crop production -a review. Agri. Rev., 22(2): 102-108.

Suresh Kumar, R. and Ganesh, P. 2012. Effect of different bio-composting techniques on physico - chemical and biological changes in coir pith. Int. J. Recent Scientific Res., 3(11): 914 - 918. 
Thampan, P.K. 2000. Recycling of coconut biomass for sustainable production. Indian coconut J., 7: 5-6.

Theradimani, M. and Marimuthu, T. 1993b. Effect of decomposed coconut coir pith on damping-off of chillies and root rot of blackgram. Plant Dis. Res., 8: 1-5.

Thomas, G.V., Palaniswami, C., Prabhu, S.R., MuraliGopal and Gupta, A. 2013. Cocomposting of coconut coir pith with solid poultry manure. Curr. Sci., 104(2): 25.

Thompson, A.K., Been, B.O. and Perkins, C. 1974. Effects of humidity on ripening of plantain bananas. Experientia, 30: 3536.

Treder, J. 2008. The effects of cocopeat and fertilization on thegrowth and flowering of oriental lily 'star gazer'. J. Fruit Ornamental Plant Res., 16: 361-370.

Treder, J. and Nowak, J. 2002. Zastosowaniepodłoży kokosowych w uprawieroślinrabatowych. Zesz. Probl. Post. Nauk Rol., 485: 335-358 (in Polish with English abstract).
Uthiah, B.C., Indiresh, K.M. and Shetty, P.T.K. 1993. Preliminary studies on the effect of mulches and irrigation on growth of young coconut plants in coastal Karnataka. Indian Coconut J., 24(6): 5-9.

Wang, T.S.C., Yang, T.K. and Chuang, T.T. 1967. Soli phenolic acids as plant growth inhibitors. Soil Sci., 103: 239246.

Warrier, K.C.S., Kumar, K.G.A. and Venkalaramanau, K. 1998. A low cost rooting medium for macropropagation of eucalyptus. Sylva Plus, 6: 13.

Yahya, A., Anieza, S.S., Rosli, B.M. and Ahmad, S. 2009. Chemical and Physical Characteristics of Cocopeat-Based Media Mixtures and Their Effects on the Growth and Development of Celosia cristata. American J. Agri. Biol. Sci., 4(1): 63-71.

Yau, P.Y. and Murphy, R.J. 1998. Enhanced biodegradation of coco peat by soft rot fungi. Paper presented at the 29th Annual Meeting of the IRG, Maastricht, The Netherlands 14-19th June, 1998.

\section{How to cite this article:}

Shiva Kumar Udayana, Anandkumar Naorem and Naorem Arunkumar Singh. 2017. The Multipurpose Utilization of Coconut By-Products in Agriculture: Prospects and Concerns. Int.J.Curr.Microbiol.App.Sci. 6(6): 1408-1415. doi: https://doi.org/10.20546/ijcmas.2017.606.165 